\title{
BEDRE ERFARINGER MED LEGENE
}

Norske pasienter rapporterer om bedre erfaringer med legene og pleiepersonellet ved norske sykehus sammenliknet med i 2011 og 2012.

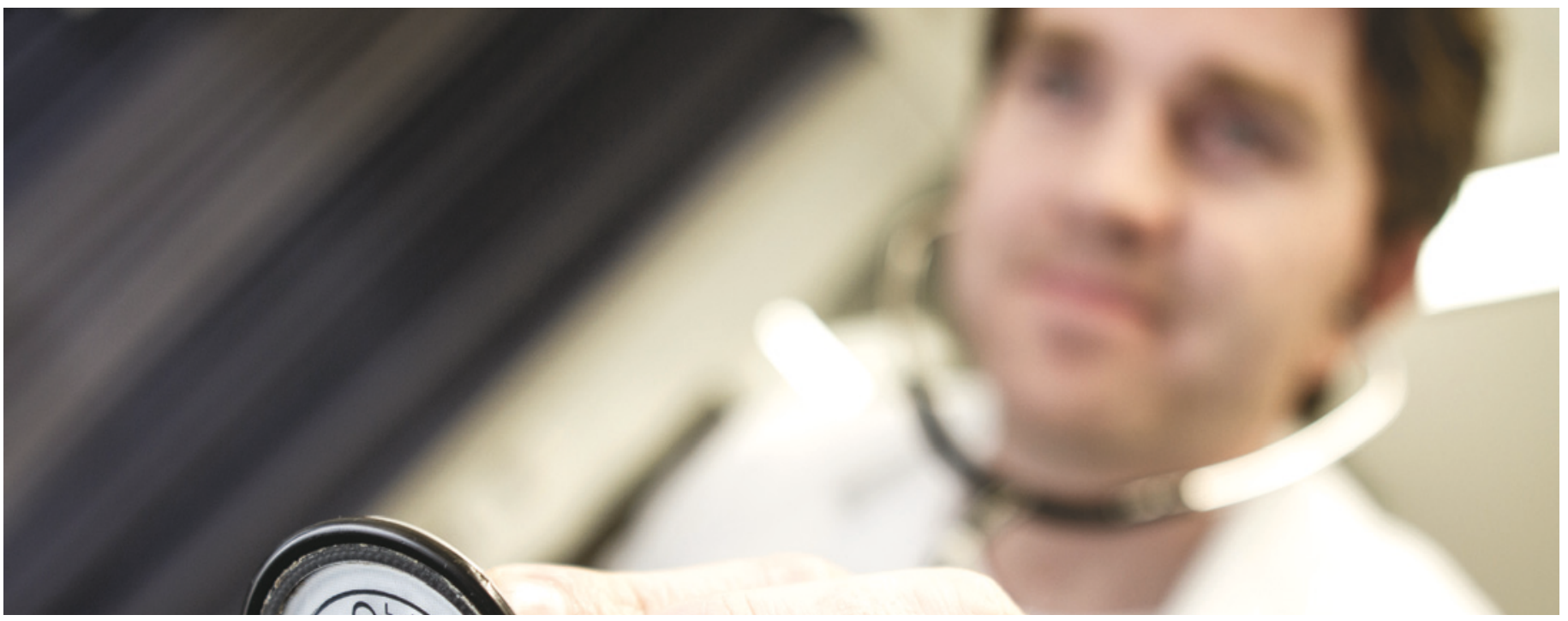

Foto: Ole Kristian Losvik

I perioden 2012-13 rapporterer de også bedre erfaringer med hvordan sykehusene informerer og organiserer arbeidet. Små sykehus kommer bedre ut enn store.

Det viser en spørreskjemaundersøkelse Kunnskapssenteret har gjennomført blant over 13000 sykehuspasienter i 2013 (1). Pasientene er spurt om sine erfaringer på ti områder, og har gitt en karakter mellom 0 og 100 .

Mest fornøyd med pasientsikkerheten I alle de tre årene undersøkelsen er gjort, har pasientsikkerheten kommet best ut. På en skala fra 0-100 gis sykehusene en gjennomsnittsskår for pasientsikkerhet på 89. Ivaretagelse av pårørende kommer nest best ut, med en skår på 76.

Pleiepersonellet gis en skår på 76, legene får 75. I 2011 og 2012 var tallene henholdsvis 73 og 75 for pleierne og 72 og 73 for legene.

Det er særlig på tre områder pasientene mener det er mer å hente.

- Pasientene mener det spesielt er et forbedringspotensial ved forberedelsen til tiden etter utskriving. De mener også at områdene samhandling og ventetid kan forbedres. Dette er de samme områdene som skåret lavest i tidligere undersøkelser, sier seniorforsker Anne Mette Bjerkan i Kunnskapssenteret.

\section{Små sykehus mest populære}

Undersøkelsen viser resultater fra alle landets sykehus og spesialistinstitusjoner, i tillegg til hvert helseforetak og regionale helseforetak. Fortsatt varierer pasientenes erfaringer betydelig mellom sykehusene, og det er de små sykehusene som kommer best ut.

De som skiller seg positivt ut på flere områder er blant annet Sykehuset Innlandet Tynset, Klinikk Rjukan, Feiringklinikken, Glittreklinikken, Revmatismesykehuset Lillehammer, Kysthospitalet Hagevik og Lærdal sjukehus.

Tilsvarende har pasienter ved Sykehuset Østfold og Klinikk Hammerfest noe dårligere erfaringer enn landsgjennomsnittet.

De ti områdene som er undersøkt, er informasjon, pleiepersonell, leger, organisering, ivaretagelse av pårørende, sykehusstandard, utskriving, samhandling, ventetid og pasientsikkerhet. Det innsamlede materialet vil bli fulgt opp med flere analyser utover høsten.

\section{Eline Feiring}

Tidsskriftet

\section{Litteratur}

1. Pasienterfaringer med norske sykehus i 2013. Nasjonale resultater. http://kunnskapssenteret. no/nyheter/_attachment/22708?_ts=1483aecf981 (9.9.2014).
«Små sykehus

kommer bedre ut

\section{enn store»}

